\title{
ПІДГОТОВКА МАЙБУТНІХ УЧИТЕЛІВ ДО ФОРМУВАННЯ МІЖОСОБИСТІСНИХ ВЗАЕМИН В УЧНІВСЬКОМУ КОЛЕКТИВІ ЯК СКЛАДНИК ОВОЛОДІННЯ ПРОФЕСІЙНИМИ КОМПЕТЕНЦІЯМИ
}

\begin{abstract}
Чорній М. М. Підготовка майбутніх учителів до формування міжособистісних взаємин в учнівському колективі як складник оволодіння професійними компетенціями.

У статті проаналізовано особливості підготовки майбутнього вчителя до формування міжособистісних взаємин в учнівському колективі підлітків в умовах компетентнісного підходу.

Ключові слова: міжсособистісні взаємини, учнівський колектив підлітків, компетентність, компетентнісний підхід, технологія.

Чорний М. Н. Подготовка будущих учителей к формированию межличностных отномений в коллективе учеников как составляющая овладением профессиональными компетенциями.

В статье проанализированы особенности подготовки будущих учителей к формированию межличностных отношений в ученическом коллективе подростков в условиях компетентносного подхода.

Ключевые слова: межличностные отночения, ученический коллектив подростков, компетентность, компетентностный подход, технология.

Chorniy M. Preparing future teachers to the formation of interpersonal relationships in a group of students as part of the mastery of professional competencies.

This article presents an analysis of peculiarities of the future teacher training to the formation of interpersonal relations in the teenage pupil group in terms of competence approach. technology.

Key words: interpersonal relations, teenage pupil group, competence, competence approach,
\end{abstract}

Актуальність проблеми. На думку більшості науковців, педагогічна діяльність соціально значуща і відіграє важливу роль у розвитку національної свідомості і гуманізації суспільства, виховання на засадах моральності й етики. Діяльність учителя вимагає не лише теоретичних знань, умінь, а й сформованості його професійної культури, інтелектуального, морального й духовного потенціалів. Сучасний учитель має володіти необхідною творчою базою, уміннями діагностики та корекції, правильного визначення мети навчально-виховного процесу i вибору оптимальних методів для іiі досягнення, вміти створювати умови для емоційного благополуччя вихованців і реалізовувати освітні технології.

Аналіз останніх досліджень і публікацій. У сучасній педагогічній науці залишаються поширеними основні методологічні підходи до організації підготовки майбутнього учителя: системний (Ю. Бабанський, В. Беспалько, Н. Кузьміна, А. Макаренко, В. Сухомлинський, С. Шацький та інші), діяльнісний (К. Абульханова-Славська, В. Бондар, В. Беспалько, Н. Кузьміна, Н. Тализіна та інші), компетентнісний (І. Зимня, Л. Карпова, О. Маркова, О. Овчарук, О. Пометун, О. Савченко та інші), синергетичний (Б. Ананьєв, П. Анохін, А. Добряков, С. Кульневич, І. Пригожий та інші), 
акмеологічний (К. Альбуханова-Славська, О. Бодальов, А. Деркач, О. Маркова та інші), аксіологічний (I. Бех, І. Зязюн, 3. Карпенко, О.Савченко, О. Сухомлинська та інші), особистісно зорієнтований (І. Бех, С. Єрмакова, Є. Бондаревська., I. Якиманська та інші), антропологічний і культурологічний (В. Сластьонін) як різновиди гуманістичного підходу (Н. Гузій, Є. Ільїн, В. Шаталов та інші).

Мета статті. На зміну традиційним підходам у системі освіти стає дедалі актуальнішим компетентнісний підхід (Н. Селезньова, В. Болотова, Л. Боголюбов), який виник у зв'язку з модернізацією змісту освіти, оптимізацією способів та технологій організації навчального процесу, підвищенням якості освіти, переосмисленням іiі цілі та результату. Компетентнісний підхід розглядається в контексті Болонського процесу, підсилює власне практичну зорієнтованість освіти, іiї прагматичний, предметно-професійний аспект [1]. Цей підхід не протиставляється знанням, умінням, навичкам, тому що підкреслює роль досвіду, умінь практично реалізовувати знання, розв'язувати завдання, але і не ототожнюється, оскільки фіксує та встановлює підпорядкування знань умінням, зосереджуючи увагу на практичному аспекті проблеми.

Виклад основного матеріалу. Дослідження явища професійної компетентності представлено у працях багатьох вітчизняних і зарубіжних науковців. Проте, з-поміж науковців немає однозначності у трактуванні поняття «компетентність».

У дослідженнях Н. Кузьміної професійно-педагогічна компетентність розглядається за фахом і трактується «як властивість особистості», сукупність умінь педагога як суб'єкта педагогічного впливу особливим чином структурувати наукове і практичне знання задля найкращого розв'язання педагогічних завдань [3, с. 90]. Професійно-педагогічну компетентність, на думку Н. Кузьміної, становлять п’ять компонентів чи видів компетентності:

1. Спеціальна і професійна компетентність свого предмета.

2. Методична компетентність стосується способів формування знань $\mathrm{i}$ умінь учнів.

3. Соціально-психологічна компетентність у сфері процесів спілкування.

4. Диференційно-психологічна компетентність у межах мотивів, здібностей учнів.

5. Аутопсихологічна компетентність на фоні переваг та недоліків власної діяльності й особистості [3, с. 90].

У роботах О. Маркової зміст професійної компетентності педагога характеризується процесуальним і результативним елементами. Дослідниця визначає професійну компетентність фахівця як «здатність та готовність виконувати особисту професійну діяльність» [5].

На основі аналізу психолого-педагогічної літератури можна визначити, що поняття «компетентність» ширше, ніж знання, уміння та навички, оо їх охоплює. Поняття «компетентність» містить, окрім когнітивної й операційнотехнологічної сфери, мотиваційний, етичний, соціальний й поведінковий складники. 
Проте, на сучасному етапі у науковій літературі немає єдиного визначення поняття компетентності, а також виокремлення ключових компетенцій. Часто терміни «компетентність» $\mathrm{i}$ «компетенція» не розмежовують і вживають як синоніми.

У психолого-педагогічній літературі термін компетенція вживається як низка завдань, для розв'язання яких необхідний певний досвід. Наявні інші підходи у витлумаченні цих понять: компетенція - це здатність фахівця до самостійної й відповідальної діяльності у сфері певних професійних завдань, на яку поширюються необхідні повноваження; поняття «компетенція» означає сукупність повноважень, прав і обов'язків; індивідуальну характеристику рівня відповідності вимогам професії [7; 5].

Ми розуміємо компетенцію як готовність фахівців до реалізації діяльності, яка грунтується на отриманих у процесі професійної підготовки знаннях та уміннях, спрямована на успішну професійну діяльність.

На основі сформульованих у зарубіжній психології положень стосовно того, що людина є суб'єктом спілкування, пізнання, праці (Б. Ананьєв), людина виявляється у системі взаємозв'язків із суспільством, 3 іншими людьми, до праці (В. М'ясищев), що професіоналізм охоплює компетентності (А. Маркова) виокремлюють три основні групи компетентностей:

- компетенції, що належать людині як особистості, суб'єкту діяльності і спілкування;

- компетенції, що стосуються соціальної взаємодії людини та соціальної галузі;

- компетенції, що стосуються діяльності людини [2].

Науковці по-різному класифікують види компетентності, проте 3-поміж ключових компетенцій всі виокремлюють соціальну компетентність. Соціальна компетентність може розглядатися як узагальнене поняття, що відображає рівень соціалізації людини (Ж. Делор, Н. Рототаєва), складник ключової компетенції (В. Хутмахер), особистісна ознака, що забезпечує взаємодію людини зі світом, як ознака «впевненості в собі» (В. Ромек, Г. Сівкова). Більшість науковців підкреслює, що соціальна компетентність виявляється в комунікативності,умінні працювати в команді, розв'язувати конфлікти.

Нам імпонує підхід Н. Кузьміної [3] до класифікації компетентностей відповідно до змісту професійної педагогічної діяльності, оскільки професійна діяльність учителя полягає в системі взаємодії з вихованцями, в якій за допомогою різних засобів упливу на учнів розв'язуються завдання навчальновиховного процесу, то найголовніший елемент професійної педагогічної компетентності, на нашу думку, становить соціально-психологічна компетентність - оволодіння педагогічною діагностикою, уміння будувати педагогічно доцільні взаємини з учнями, реалізовувати індивідуальну роботу, знання вікової психології, психології міжособистісного та педагогічного спілкування. Соціальна компетентність педагога - це вміння налагоджувати адекватні міжособистісні стосунки в різних ситуаціях. Соціальна компетентність має свої підгрупи, де провідне місце належить компетентності спілкування i 
компетентності соціальної взаємодії як здатності адекватного взаєморозуміння, залежно від ситуацій, уникнення конфліктів, створення сприятливого психологічного клімату, формування міжособистісних взаємин в учнівських колективах.

Дотримуючись концептуальної позиції, що компетентність - це готовність фахівця успішно і продуктивно реалізовувати професійну діяльність, доцільно розглядати підготовку майбутнього вчителя до формування міжособистісних взаємин в учнівському колективі підлітків, по-перше, як набуття майбутнім педагогом компетентності, яка охоплює соціальний, мотиваційний, функціональний підвиди та, по-друге, як сформованість ціннісно-мотиваційного, когнітивного і функціонально-технологічного компонентів готовності.

Виходячи з системи класифікації та ієрархії компетентностей, запропонованої О. Крисаном [4], яка передбачає надпредметні, загально-предметні й соціально-предметні компетентності, будемо розглядати підготовку майбутнього вчителя до формування доцільних міжособистісних взаємин в учнівському колективі підлітків як комплексне оволодіння ними. Набуття надпредметних компетентностей дозволяє педагогу ефективно здійснювати професійну діяльність, загально-предметні компетентності формуються у процесі професійної підготовки загалом, предметні компетентності педагог набуває у процесі вивчення конкретного курсу чи дисципліни.

Українські педагоги $[4 ; 6 ; 8]$ визначають ключові компетентності не лише як комплекс певного рівня знань, умінь, навичок та ставлень, здатність здійснювати професійну діяльність, а як оволодіння комплексом знань та вмінь особистісно-діяльнісного характеру, і пропонують перелік базових компетентностей, що охоплюють: уміння вчитися, громадянську, загальнокультурну, компетентність 3 інформаційних та комунікаційних технологій, соціальну, підприємницьку і здоров'язберігальну.

У підготовці майбутнього учителя до формування гармонійних міжособистісних взаємин в учнівському колективі підлітків у межах компетентнісного підходу важливими аспектами є оволодіння соціальною i здоров'язберігальною ключовими компетентностями. Соціальна компетентність включає здатність підтримувати й керувати взаєминами 3 іншими, продуктивно співпрацювати 3 різними партнерами у групі, виявляти ініціативу, застосовувати ефективні стратегії спілкування, створювати i реалізовувати проекти індивідуальних та колективних дій, конструктивно розв'язувати конфлікти. Здоров'язберігальна компетентність містить характеристики особистості, спрямовані на збереження іiі фізичного, психічного, духовного здоров'я й оточення.

Висновки та перспективи подальших розвідок. Здійснений аналіз наукових джерел дозволяє стверджувати, що важливим складником професійно-педагогічної компетентності $є$ власна соціально-психологічна компетентність - вміння майбутнього вчителя виконувати колективну діяльність, готовність створювати сприятливий психологічний клімат у колективі вихованців, будувати й оптимізувати оптимальні міжособистісні взаємини з учнями, колегами, батьками. 
Успіх педагогічної діяльності визначається не тільки рівнем професійної підготовки вчителя, рівнем знань, які він отримав під час навчання у вищому навчальному закладі, а й від активності та бажання підвищувати рівень професійної компетентності, від сформованої особистісної позиції. Тому, на наш погляд, підготовка до створення гармонійних міжособистісних взаємин в учнівському колективі підлітків як складника професійних компетенцій майбутнього вчителя буде успішною за умови забезпечення його цілісного професійного й особистісного становлення, а також інформування щодо специфіки педагогічної професії, свідомого її вибору та критичної оцінки власних можливостей.

Науковці стверджують, що сучасний учитель переважно акцентує увагу на виконанні вимог програми, при цьому залишаючи осторонь учня, його внутрішній світ. Це зумовлюється не відсутністю бажання в педагогів, а необізнаністю з психологічними особливостями учнів. Проблема полягає в тому, що підготовка майбутніх учителів спрямована на засвоєння готових знань, далеких від практичної діяльності. Компетентнісний підхід підвищує практичну зорієнтованість освіти, зумовлює необхідність посилення акценту на операційній характеристиці результату. Випускники педагогічних навчальних закладів повинні не лише знати, що реалізовувати у своїй педагогічній діяльності, а й уміти це робити. Професійна підготовка майбутніх учителів має забезпечувати готовність спеціалістів до таких аспектів їхньої діяльності, сприяти не лише засвоєнню теоретичних знань, а стимулювати до пошуку адекватних способів та прийомів розв'язання завдань навчального процесу.

Отже, важливим аспектом у процесі професійно-педагогічної підготовки майбутніх учителів є оволодіння ними соціально-психологічною компетентністю, що передбачає знання психології міжособистісного та педагогічного спілкування, вміння здійснювати колективну діяльність, уникати конфліктів, створювати сприятливий клімат у колективі вихованців, оптимізувати міжособистісні взаємини в ньому.

\section{Література}

1. Боголюбов Л. Н. Базовые социальные компетенции в курсе обществоведения / Л. Н. Боголюбов // Преподавание истории и обществознания в школе. - 2002. - № 9. - С. 5.

2. Зимняя И. А. Ключевые компетенции - новая парадигма результата образования : [Электронный ресурс] / И. А. Зимняя // Режим доступа: www.aspirant.rggu.ru

3. Кузьмина Н. В. Профессионализм личности преподавателя и мастера производственного обучения / Н. В. Кузьмина. - М.: Просвещение, 1990. - 119 с.

4. Луговий В. І. Компетентності та компетенції: поняттєво-інформаційний дискурс / В. І. Луговий // Вища освіта України. - №3 (додаток 1) - Тематичний випуск «Педагогіка вищої школи: методологія, теорія, технології». - К.: Генезис, 2009. - 630 с. - С.11.

5. Маркова А. К. Психологические критерии и ступени профессиональности учителя / А. К. Маркова // Педагогика. - 1995. - № 6. - С. 7.

6. Хоружа Л. Л. Етична компетентність майбутнього вчителя початкових класів: теорія і практика: [монографія] / Л. Л. Хоружа. - К. : Преса України, 2003. - 320 с.

7. Хуторской А. В. Ключевые компетенции и образовательные стандарты: Доклад на отделении философии образования и теории педагогики [Электронный ресурс] / A. В. Хуторской // РАO. - 23 апреля 2002 //Режим доступа: www.eidos.ru 
8. Цимбал С. В. Синергетичний та акмеологічний аспекти формування професійної компетентності студентів / С. В. Цимбал, О. В. Вознюк, С. О. Кубіцький // Нові технології навчання: [наук.-метод. зб.]. - К. : Науково-методичний центр вищої освіти, 2005. - Випуск 40. - 279 с.

Стаття надійшла до редакції 13.05.2012 р.

УДК 377.35

О. П. Крупський, кандидат психол. наук, дочент,

К. С. Кіба,

Дніпропетровський націіональний університет ім. О. Гончара

\section{ВЗАЕМОЗВ'ЯЗОК МІЖ ЕМОЦІЙНОЮ КОМПЕТЕНТНІСТЮ ТА ЛІДЕРСТВОМ ЯК СКЛАДНИКАМИ ПЕДАГОГІЧНОЇ ДІЯЛЬНОСТІ}

Крупський О. П., Кіба К. С. Взасмозв'язок між емоційною компетентністю та лідерством як складниками педагогічної діяльності.

Статтю присвячено проблемі взаємозв'язку емоційного інтелекту та лідерства, їх впливу на педагогічну діяльність, а також виявленню залежності між емоційним інтелектом вчителів та учнів середніх і вищих навчальних закладів. лідерства.

Ключові слова: лідерство, мотивачія, емоційний інтелект, компетениї̈, стилі емоційного

Крупский А. П., Киба К. С. Взаимосвязь между эмоииональной компетентностью и лидерством как составляющими педагогической деятельности.

Статья посвящена проблеме взаимосвязи эмочионального интеллекта и лидерства, их влияния на педагогическую деятельность, а также выявлению связи между эмоциональным интеллектом учителей и учеников средних и высших учебных заведений.

Ключевые слова: лидерство, мотивация, эмочиональный интеллект, компетенции, стили эмочионального лидерства.

Krupsky O., Kiba K. Interrelation between emotional competence and leadership as components of pedagogical activity.

The article is devoted to a problem of interrelation of emotional intelligence and leadership, their influence on pedagogical activity, and also communication identification between emotional intelligence of teachers and pupils of averages and higher educational institutions.

Key words: leadership, motivation, emotional intelligence, competences, styles of emotional leadership.

У сучасних умовах робота педагогічного колективу стає все більш емоційно напруженою, зростає відповідальність за навчальну успішність учнів при дефіциті матеріальних, фінансових та трудових ресурсів. Іноді особистісний потенціал педагога виявляється нижче або вище за потенціал, якого вимагає посадовий рівень. Недосконалість управлінської вертикалі та умов праці, у свою чергу, призводять до конфліктів, особистісних деформацій та до різного роду психосоматичних захворювань серед вчителів та учнів.

Важливим компонентом у структурі особистості педагога є професійно важливі якості. В. Шадриков під професійно важливими якостями розуміє індивідуальні якості суб'єкта діяльності, що впливають на ефективність діяльності й успішність їі засвоєння [15]. До професійно важливих якостей він відносить також і здібності. Домінантними якостями у професійно- 